\title{
Pengaruh Religiusitas dan Lokasi Terhadap Keputusan Pembelian Konsumen Pada Rahmat Syariah Swalayan City Walk Padangsidimpuan
}

\section{Muhammad Isa}

Institut Agama Islam Negeri Padangsidimpuan misastmm@gmail.com

\section{H. Aswadi Lubis}

Institut Agama Islam Negeri Padangsidimpuan aswadilubis63@gmail.com

\section{Ilma Sari Lubis}

Institut Agama Islam Negeri Padangsidimpuan ilmasariiain@gmail.com

\begin{abstract}
Abstrak
Penelitian ini bertujuan untuk mengetahui pengaruh variabel religiusitas dan lokasi terhadap keputusan pembelian konsumen pada Rahmat Syariah Swalayan City Walk Padangsidimpuan. Penelitian ini dilatarbelakangi oleh jumlah konsumen Rahmat Syariah Swalayan City Walk Padangsidimpuan sampai saat ini belum sesuai dengan harapan. Penelitian ini adalah penelitian kuantitatif dengan teknik regresi linear berganda. Pengumpulan data menggunakan angket yang disebar kepada 69 orang responden. Pengolahan data dilakukan dengan bantuan software SPSS. Dari penelitian yang dilakukan ditemukan bahwa secara simultan variabel religiusitas dan variabel lokasi memiliki pengaruh yang signifikan terhadap keputusan pembelian konsumen pada Rahmat Syariah Swalayan City Walk Padangsidimpuan dengan kontribusi sebesar 92,3\%, sedangkan sisanya 7,7\% dipengaruhi oleh variabel lain yang tidak diteliti dalam penelitian ini. Dalam hal ini variabel religiusitas dan variabel lokasi memiliki pengaruh positif terhadap keputusan pembelian konsumen pada Rahmat Syariah Swalayan City Walk Padangsidimpuan.
\end{abstract}

Kata Kunci Pengaruh, Religiusitas, Lokasi, Keputusan Pembelian

\begin{abstract}
This research aims to know the influence of religiosity and location to consumer purchasing decisions in Rahmat Syariah Swalayan City Walk Padangsidimpuan. The background of this research is total daily customers are still below expectations. This is a quantitative research and use multiple linear regression technique. This research use questionnaires with 69 consumers as samples and data processing with Software SPSS. From this research researcher know that Religiosity and Location have positive and significant influence to Consumer Purchasing Decisions in Rahmat Syariah Swalayan City Walk Padangsidimpuan. The contributes of Religiosity and Location to Consumer Purchasing Decisions are 92,3\% and 7,7\% explained by others variables. Religiosity and Location have positive effect to Consumer Purchasing Decisions in Rahmat Syariah Swalayan City Walk Padangsidimpuan
\end{abstract}

Key words Effect, Religiosity, Location, Consumer Purchasing Decisions 


\section{PENDAhuluaN}

Bisnis eceran (retail) telah menjadi salah satu sektor bisnis yang berkembang saat ini. Kata retail berasal dari bahasa Prancis yang bermakna memotong atau membagi dalam bagian yang lebih kecil. Bisnis eceran atau ritel adalah kegiatan menjual barang atau jasa kepada konsumen untuk dipakai sendiri. Dengan kata lain bisnis eceran merupakan kegiatan menjual produk atau jasa kepada konsumen akhir dan sebagai tahap paling akhir dalam proses distribusi.

Biasanya usaha eceran menggunakan sarana tempat seperti toko, namun ada juga yang menggunakan vending machine, door to door, direct selling, mail order, kaki lima dan sebagainya. Kehadiran pedagang eceran sangat penting bagi konsumen dalam memperoleh produk atau jasa untuk memenuhi kebutuhannya. Saat ini bisnis eceran sudah menjadi bagian yang tidak terpisahkan dari kehidupan masyarakat dan menjadi bagian dari siklus ekonomi ( membeli dari produsen dan menyalurkannya kepada konsumen)

Di Indonesia sudah lama dikenal istilah: toko kelontong, supermarket, toko swalayan, mall, department store, dan sebagainya. Kesemuanya merupakan sebagian contoh dari bisnis eceran. Seiring dengan perubahan gaya hidup dan kemajuan peradaban manusia, ada kecendrungan perubahan cara berbelanja masyarakat dari yang semula lebih terkonsentrasi di pasar tradisional menuju pasar perbelanjaan modern. Sebagai indikator perubahan itu terlihat dari tumbuh suburnya beberapa perusahaan besar yang berkecimpung di bisnis eceran ini antara lain: grup Indomaret, Alfa-Mart, Alfamidi, Suzuya, Ramayana, dan sebagainya.

Kemajuan bisnis ritel ini sangat berkaitan dengan kondisi perekonomian nasional. Ketika kondisi perekonomian secara umum baik dimana daya beli masyarakat cukup tinggi maka sebuah lembaga bisnis ritel akan dapat tumbuh dan berkembang. Namun dalam keadaan perekonomian nasional yang tidak menguntungkan maka daya beli masyarakat akan menurun drastis. Hal ini mengakibatkan melambannya pertumbuhan sektor bisnis ritel atau bahkan mengalami penurunan. Indonesia pernah mengalami krisis ekonomi yang cukup parah pada tahun 1998 yang mengakibatkan hampir semua sektor bisnis mengalami kemunduran termasuk sektor bisnis ritel.

Sejalan dengan semakin membaiknya tingkat perekonomian secara nasional maka sektor bisnis ritel di Indonesia kembali bangkit dan berkembang. Bisnis eceran ini tidak hanya terdapat di kota-kota besar namun juga merambah kota-kota kecil bahkan telah sampai ke pedesaan. Bisnis eceran ini ternyata tidak hanya digeluti oleh pemodal besar namun juga diminati oleh para pengusaha kecil dan kelas menengah. Banyak di antara pengusaha kecil dan menengah yang membuka toko swalayan yang cukup lengkap dan modern. Tentunya hal ini menambah ketatnya persaingan antar perusahaan bisnis ritel di setiap daerah. Terjadi persaingan yang sengit antara pengusaha bisnis ritel lokal dengan pengusaha bisnis ritel raksasa yang jaringannya hampir mencakup seluruh penjuru tanah air.

Kondisi di atas terjadi juga di Kota Padangsidimpuan. Kota Padangsidimpuan merupakan salah satu kota yang terdapat di Sumatera Utara dan menjadi salah satu pusat perekonomian di wilayah pantai barat Sumatera Utara. Kota ini cukup strategis karena menjadi jalur penghubung kota Medan dan Padang. Selain itu kota juga menjadi penghubung kota Sibolga dengan Pekanbaru, dan sebaliknya. Di kota ini banyak berdiri perguruan tinggi seperti: IAIN Padangdisimpuan, Universitas Muhammadiyah Tapanuli Selatan, Universitas Aufa Royhan, Universitas Graha Nusantara, STIKES Syuhada, STMIK, dan sebagainya. Oleh karena itu kota ini memiliki daya tarik tersendiri bagi pengusaha yang tertarik di bidang bisnis ritel.

Salah satu perusahaan bisnis ritel yang telah lama berdiri di kota Padangsidimpuan adalah Rahmat Syariah Swalayan. Perusahaan ini telah memiliki tiga unit usaha yang tersebar di kota Padangsidimpuan, yaitu Rahmat Syariah Swalayan Aek Tampang, Rahmat Syariah Swalayan Sitamiang, dan Rahmat Syariah Swalayan City Walk. Saat ini beberapa perusahaan bisnis ritel besar telah beroperasi di kota Padangsidimpuan, antara lain Indomaret dan Alfamidi. Hal ini tentu menambah sengitnya persaingan antar perusahaan bisnis ritel di wilayah ini. Dalam menghadapi persaingan ini setiap perusahaan akan menerapkan strategi pemasaran mereka masing-masing. Rahmat Syariah Swalayan selama ini mengenalkan dirinya sebagai perusahaan yang islami. Hal ini tercermin dari penggunaan kata "syariah" yang melekat pada nama perusahaan ini. Selain itu perusahaan ini juga mempekerjakan karyawan yang mayoritas muslim. Nilai religius yang ditawarkan Rahmat Syariah Swalayan menjadi daya tarik tersendiri bagi masyarakat kota Padangsidimpuan yang mayoritas muslim. Walaupun harus diakui sampai saat ini Rahmat Syariah Swalayan masih sering mendapat tudingan sebagai perusahaan 
yang sebenarnya sama saja dengan swalayan konvensional dimana istilah "syariah" digunakan hanya sebagai strategi pemasaran semata.

Pengelola Rahmat Syariah Swalayan telah berusaha untuk memberikan pelayanan yang terbaik bagi masyarakat Padangsidimpuan dengan menetapkan lokasi perusahaan ini di tempat yang strategis dan dilalui kenderaan umum. Hal ini bertujuan agar masyarakat mudah menjangkaunya dan memperoleh kebutuhannya dengan cepat. Lokasi adalah letak yang strategis dari jangkauan konsumen. Lokasi yang strategis akan menjadi pilihan konsumen dalam melakukan pembelian. Lokasi yang bagus tidak hanya berada di pusat pasar tetapi di permukiman masyarakat. Lokasi merupakan tempat melayani konsumen, dapat pula diartikan sebagai tempat untuk memanjangkan barang-barangnya.

Salah satu unit usahan Rahmat Syariah Swalayan berlokasi di kawasan City Walk Padangsidimpuan. Berdasarkan wawancara dengan Bapak AF, Pengelola Rahmat Syariah Swalayan, tanggal 10 Juli 2018, ternyata jumlah pengunjung Rahmat Syariah Swalayan City Walk belum seperti yang diharapkan. Hal ini terlihat dari jumlah pengunjung rata-rata perhari hanya sebanyak 50 orang. Padahal kapasitas kasir dapat melayani pelanggan sebanyak 100 orang perhari. Kenyataan ini menjadi penting untuk diteliti sehingga dapat diambil langkah-langkah perbaikan strategi pemasaran perusahaan ini ke depan.

Keunikan swalayan ini adalah dicantumkannya kata "syariah" pada nama resmi swalayan ini disertai pelayanannya yang bernuansa religius bila dibandingkan dengan swalayan lainnya di Kota Padangsidimpuan. Lokasi swalayan ini juga cukup strategis karena berada di pusat kota Padangsidimpuan, yaitu di Komplek Pertokoan City Walk Padangsidimpuan. Oleh karena itu penting untuk diteliti bagaimana pengaruh dan kontribusi nilai religiusitas dan lokasi swalayan yang strategis terhadap keputusan konsumen untuk berbelanja di Rahmat Syariah Swalayan City Walk Padangsidimpuan.

\section{TINJAUAN PUSTAKA}

\section{Keputusan Pembelian}

Kebiasaan konsumen dalam membeli adalah suatu cara yang dilakukan konsumen dalam bertindak pada proses pembelian barang, jasa atau penerimaan konsumen akan sebuah ide. Seorang pemasar yang baik harus lebih memahami kebiasaan konsumennya daalam kegiatan berbelanja. Informasi yang dibutuhkan oleh pengecer dalam rangka memahami kebiasaan konsumennya dalam membeli adalah hal-hal yang berhubungan dengan apa dan berapa banyak konsumen membeli, siapa yang melakukan pembelian serta bagaimana dan dimana konsumen membeli.

Proses keputusan pembelian dapat dikategorikan ke dalam tiga tahapan utama, yaitu: pra pembelian, konsumsi, dan evaluasi purna beli. Tahap pra pembelian merupakan semua aktivitas konsumen yang terjadi sebelum terjadinya transaksi pembelian dan pemakaian produk. Tahapan yang pertama ini meliputi identifikasi kebutuhan, pencarian informasi dan evaluasi alternatif. Tahap konsumsi merupakan tahapan di mana konsumen membeli dan menggunakan produk atau jasa. Sedangkan tahap evaluasi purna beli adalah tahapan dimana pembeli mengevaluasi apakah ia telah membuat keputusan pembelian yang tepat.

\section{Gambar 1. Proses keputusan pembelian}

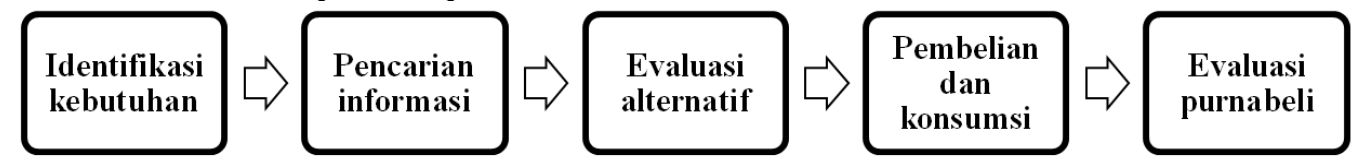

Kesemua proses keputusan pembelian di atas dilalui jika konsumen melakukan pembelian berketerlibatan tinggi (high-involvement purchases), yaitu situasi pembelian yang secara psikologis penting bagi konsumen karena menyangkut kebutuhan sosial atau self-esteem, serta memiliki persepsi risiko yang besar (risiko sosial, risiko psikologis, dan risiko finansial). Sementara dalam situasi pembelian berketerlibatan rendah, proses pencarian informasi dan evaluasi alternatif berlangsung dalam tingkatan minimum. Bahkan sering terjadi keputusan pembelian secara impulsif (tanpa perencanaan).

Fandy Tjiptono (2015:54) menjabarkan perbedaan antara perilaku konsumen berketerlibatan tinggi dan rendah sebagai berikut: 
Tabel 1. perbedaan antara perilaku konsumen berketerlibatan tinggi dan rendah

\begin{tabular}{|l|l|}
\hline Perilaku konsumen berketerlibatan tinggi & Perilaku konsumen berketerlibatan rendah \\
\hline Konsumen adalah pemroses informasi & Konsumen mempelajari informasi secara acak \\
\hline Konsumen adalah pencari informasi & Konsumen adalah pengumpul informasi \\
\hline $\begin{array}{l}\text { Konsumen merupakan audiens aktif bagi } \\
\text { periklanan }\end{array}$ & $\begin{array}{l}\text { Konsumen merupakan audiens pasif bagi } \\
\text { periklanan }\end{array}$ \\
\hline Konsumen mengevaluasi merek sebelum membeli & $\begin{array}{l}\text { Konsumen membeli produk atau jasa terlebih } \\
\text { dahulu. Kalaupun mereka mengevaluasi merek, itu } \\
\text { dilakukan setelah pembelian. }\end{array}$ \\
\hline $\begin{array}{l}\text { Konsumen berusaha memaksimalkan kepuasan } \\
\text { yang diharapkan. Mereka membandingkan merek } \\
\text { untuk menilai mana yang memberikan manfaat } \\
\text { terbesar bagi pemenuhan kebutuhan mereka dan } \\
\text { melakukan pembelian atas dasar perbandingan } \\
\text { multiatribut terhadap berbagai alternatif merek }\end{array}$ & $\begin{array}{l}\text { Konsumen mengupayakan tingkat kepuasan yang } \\
\text { bisa diterima. Mereka membeli merek yang } \\
\text { diyakini paling kecil kemungkinannya } \\
\text { menimbulkan masalah. Pembelian dilakukan atas } \\
\text { dasar sedikit atribut. Familiaritas merupakan kunci } \\
\text { utama. }\end{array}$ \\
\hline $\begin{array}{l}\text { Karakteristik kepribadian dan gaya hidup berkaitan } \\
\text { dengan perilaku konsumen karena produk atau jasa } \\
\text { terkait erat dengan identitas diri dan keyakinan } \\
\text { konsumen }\end{array}$ & $\begin{array}{l}\text { Karakteristik kepribadian dan gaya hidup tidak } \\
\text { berkaitan dengan perilaku konsumen karena } \\
\text { produk atau jasa tidak terkait dengan identitas diri } \\
\text { dan keyakinan konsumen }\end{array}$ \\
\hline $\begin{array}{l}\text { Kelompok referensi mempengaruhi perilaku } \\
\text { konsumen karena produk atau jasa bersangkutan } \\
\text { penting bagi norma dan nilai kelompok. }\end{array}$ & $\begin{array}{l}\text { Kelompok referensi tidak banyak berpengaruh } \\
\text { terhadap perilaku konsumen karena produk atau } \\
\text { jasa bersangkutan tidak terlalu terkait dengan } \\
\text { norma dan nilai kelompok. }\end{array}$ \\
\hline
\end{tabular}

Keputusan merupakan permulaan dari semua kegiatan manusia yang sadar dan terarah, baik secara individual, kelompok maupun secara institusional. Keputusan pada dasarnya merupakan proses memilih satu penyelesaian dari beberapa alternatif yang ada. Sule dan Saefullah (2005:116) menyatakan bahwa keputusan yang tepat pada dasarnya adalah keputusan yang bersifat rasional, sesuai dengan nurani, dan didukung oleh fakta-fakta yang akurat, sehingga dapat dipertanggung jawabkan.

Sedangkan menurut Sangadji \& Sopiah (2013:12) pengambilan keputusan adalah proses pengintegrasian yang mengombinasikan pengetahuan untuk mengevaluasi dua perilaku alternatif atau lebih, dan memilih salah satu diantaranya. Hasil dari proses pengintegrasian ini adalah suatu pilihan yang disajikan secara kognitif sebagai keinginan berperilaku. Dari penjelasan diatas, dapat ditarik kesimpulan bahwa semua perilaku sengaja dilandaskan pada keinginan yang dihasilkan ketika konsumen secara sadar memilih salah satu di antara tindakan alternatif yang ada. Keputusan konsumen untuk memutuskan untuk membeli atau mengonsumsi produk tertentu akan diawali oleh langkah-langkah seperti pengenalan masalah, pencarian informasi, evaluasi alternatif, dan lain-lain. Keputusan pembelian merupakan suatu keputusan sebagai pemilihan suatu tindakan, memutuskan membeli atau mengkonsumsi produk tertentu.

Ada banyak faktor yang memengaruhi perilaku konsumen dalam keputusan pembelian. Nugroho J. Setiadi (2010:10) menjelaskan beberapa faktor utama yang memengaruhi perilaku konsumen dalam keputusan pembelian sebagai berikut:

Pertama, Faktor Budaya. Kebudayaan merupakan faktor penentu yang paling dasar dari keinginan dan perilaku seseorang. Faktor budaya dibedakan menjadi:

a) Subbudaya, subbudaya dapat dibedakan menjadi empat jenis: kelompok nasionalisme, kelompok keagamaan, kelompok ras, dan area geografis.

b) Kelas sosial, kelas-kelas sosial adalah kelompok yang relatif homogen dan bertahan lama dalam suatu masyarakat, yang tersusun secara hirarki dan yang keanggotaannya mempunyai nilai, minat, dan perilaku yang serupa.

Kedua, Faktor-faktor Sosial. Perilaku seorang konsumen juga dipengaruhi oleh faktor-faktor sosial, seperti :

a) Kelompok referensi (reference group), kelompok referensi seseorang terdiri dari seluruh kelompok yang mempunyai pengaruh langsung maupun tidak langsung terhadap sikap atau perilaku seseorang. Beberapa diantaranya: kelompok primer, kelompok sekunder, kelompok aspirasi, kelompok diasosiatif. 
b) Keluarga (family), dapat dibedakan dua keluarga dalam kehidupan pembeli, yaitu keluarga orientasi (orang tua seseorang), keluarga prokreasi (pasangan hidup, anak-anak seseorang).

c) Peran dan status sosial, seseorang umumnya berpartisipasi dalam kelompok selama hidupnya, keluarganya, klub, organisasi.

Ketiga, Faktor-faktor Pribadi. Keputusan seorang pembeli juga dipengaruhi oleh ciri-ciri kepribadiannya, termasuk:

a) Umur dan tahapan dalam siklus hidup (life cycle stage), konsumsi seseorang juga dibentuk oleh tahapan siklus hidup keluarga.

b) Pekerjaan, para pemasar berusaha mengidentifikasi kelompok-kelompok pekerja yang memiliki minat di atas rata-rata terhadap produk dan jasa tertentu.

c) Keadaan ekonomi, keadaan ekonomi seseorang terdiri dari pendapatan yang dapat dibelanjakan (tingkatnya, staibilitasnya, dan polanya), tabungan dan hartanya (termasuk persentase yang mudah dijadikan uang), kemampuan untuk meminjam dan sikap terhadap mengeluarkan lawan menabung.

d) Gaya hidup (life style), gaya hidup seseorang adalah seseorang adalah pola hidup di dunia yang diekspresikan oleh kegiatan, minat, dan pendapatan seseorang.

e) Kepribadian dan konsep diri sendiri (self concept) yaitu karakteristik psikologis yang berbeda dari setiap orang yang memandang responnya terhadap lingkungan yang relatif konsisten.

Keempat, Faktor-faktor Psikologis. Adapun yang termasuk faktor psikologis dalam memengaruhi keputusan pembelian adalah:

a) Motivasi, beberapa kebutuhan bersifat biogenik, kebutuhan ini timbul dari suatu keadaan fisiologis tertentu, seperti rasa lapar, haus, rasa tidak nyaman. Adapun kebutuhan lain bersifat psikogenik yaitu kebutuhan yang timbul dari keadaan fisiologis tertentu, seperti kebutuhan untuk diakui, kebutuhan harga diri atau kebutuhan diterima.

b) Persepsi, didefinisikan sebagai proses dimana seseorang memilih, mengorganisasikan, mengartikan masukan informasi untuk menciptakan suatu gambaran yang berarti di dunia ini.

c) Proses belajar, menjelaskan perubahan dalam perilaku sseseorang yang timbul dari pengalaman.

d) Kepercayaan diri dan sikap seseorang, kepercayaan adalah suatu gagasan deksriptif yang dimiliki seseorang terhadap sesuatu.

\section{Religiusitas}

Para pakar pemasaran telah mengemukakan banyak faktor yang memengaruhi keputusan pembelian.Kotler dan Amstrong seperti dikutip oleh Susatyo Herlambang (2014:68) menyatakan salah satu faktor yang memengaruhi keputusan pembelian adalah faktor kebudayaan yang didalamnya ada faktor subkultur termasuk agama. Religiusitas merupakan salah satu faktor yang mempengaruhi keputusan pembelian konsumen, yaitu berada pada bagian faktor budaya yang terdapat dalam sub-budaya yaitu tentang keagamaan. Seorang yang dikatakan beragama yang baik dapat dilihat dari ketaatan kepada Tuhannya, yang diwujudkan dengan melaksanakan segala apa yang diperintahkan oleh Tuhan dan menjauhi segala apa yang dilarang-Nya.

Faiz Mujawidin dalam penelitiannya (2014:7),menemukan bahwa semakin tinggi ketaatan atau kepercayaan seseorang kepada Tuhannya, semakin tinggi pula tingkat religuisitasnya. Dimana religiusitas adalah kepercayaan kepada Tuhan yang ditandai dengan kesalehan dan semangat keagamaan. Menurut Harun Nasution dalam buku Abuddin Nata (2013:10) menyimpulkan bahwa agama mengandung arti ikatan yang harus dipegang dan dipatuhi dan mempunyai pengaruh besar terhadap kehidupan manusia sehai-hari. Ikatan itu berasal dari suatu kekuatan yang lebih tinggi dari manusia.

Menurut J.G Frazer dalam buku Abuddin Nata (2013:168) mengatakan bahwa agama adalah suatu ketundukan atau penyerahan diri kepada kekuatan yang lebih tinggi daripada manusia yang dipercaya mengatur dan mengendalikan jalannya alam dan kehidupan manusia. Lebih lanjut Frazer mengatakan bahwa agama terdiri dari dua elemen yakni yang bersifat teoritis berupa kepercayaan kepada kekuatan-kekuatan yang lebih tinggi daripada manusia dan yang bersifat praktis berupa usaha manusia untuk tunduk kepada kekuatan-kekuatan tersebut, seperti menjauhi segala yang dilarang-Nya.

Menurut Atang Abdul Hakim (2004:4) dalam bukunya Metodologi Studi Islam dijelaskan bahwa religiusitas sikap hidup seseorang berdasarkan pada nilai-nilai yang diyakininya. Religiusitas 
adalah sebuah sikap yang nampak dalam perilaku seseorang yang terinternalisasi oleh nilai - nilai atau ajaran - ajaran agama.

Sikap tersebut menjadi parameter terhadap asumsi seberapa tinggi tingkat penghayatan dan pengalaman seseorang terhadap nilai atau ajaran agama tersebut. Suatu kelompok masyarakat yang memiliki kehidupan yang semakin sejahtera, damai dan tentram, maka menunjukkan semakin tinggi pula penghayatan dan pengamalan terhadap ajaran agama. Sebaliknya jika kehidupan mereka semakin keras, kasar, tidak adanya toleransi dan jaminan keselamatan maupun kesejahteraan maka semakin gersang dan tidak terlihat perilaku keagamaan atau ke-religiusitas-an dalam hidup mereka, boleh jadi muncul asumsi bahwa agama tidak dibutuhkan oleh mereka.

Adapun religiusitas memiliki lima dimensi, antara lain :

Pertama, dimensi ideologi/keyakinan yang berisi pengharapan-pengharapan di mana orang religius berpegang teguh pada pandangan teologis tertentu dan mengakui kebenaran doktrin-doktrin tersebut. Kedua, dimensi praktik ibadah yang mencakup pada perilaku pemujaan, ketaatan, dan hal-hal yang dilakukan orang untuk menunjukkan komitmen terhadap agama yang dianutnya. Praktik-praktik agama ini terdiri dari dua kelas yang penting, yaitu:

a)Ritual, praktik ini mengacu pada seperangkat ritus, tindakan formal keagamaan serta praktik praktik suci yang mengharapkan agar dilaksanakan oleh para pemeluk agama.

b) Ketaatan, semua agama yang dikenal juga mempunyai seperangkat tindakan persembahan dan kontemplasi personal yang relatif spontan, informal dan khas pribadi.

Ketiga, dimensi pengalaman, berkaitan dengan pengalaman keagamaan, perasaan, persepsi dan sensasi yang yang dialami seseorang atau didefinisikan oleh suatu kelompok keagamaan (atau suatu masyarakat) yang melihat komunikasi, walaupun kecil, dalam suatu esensi ketuhanan, yaitu dengan Tuhan, kenyataan terakhir, dengan otoritas transendental.

Keempat, dimensi pengetahuan agama, mengacu pada harapan bagi orang-orang yang beragama paling tidak memiliki sejumlah minimal pengetahuan mengenai dasar-dasar keyakinan, ritus-ritus, kitab suci dan tradisi-tradisi dari agama yang dianut.

Kelima, dimensi pengalaman atau konsekuensi, mengacu pada identifikasi akibat-akibat keyakinan keagamaan, praktik, pengalaman dan pengetahuan seseorang dari hari ke hari. Walaupun agama banyak menggariskan bagaimana pemeluknya seharusnya berpikir dan bertindak dalam kehidupan sehari-hari, tidak sepenuhnya jelas sebatas mana konsekuensi-konsekuensi agama merupakan bagian dari komitmen keagamaan atau semata-mata berasal dari agama.

Islam menyuruh umatnya untuk beragama (atau ber-Islam) secara menyeluruh, hal ini disebutkan dalam Q.S.al-Baqarah, ayat 208, yaitu:

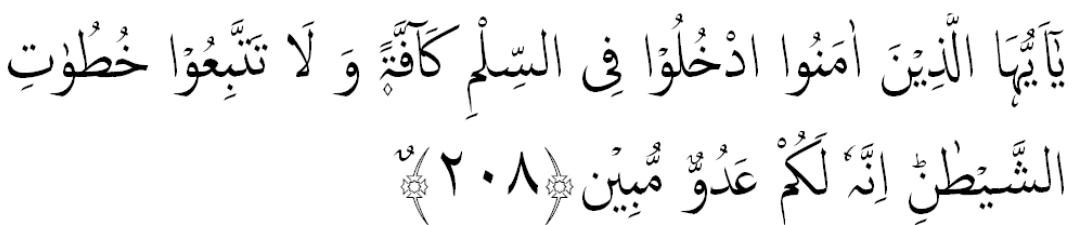

Artinya :Hai orang-orang yang beriman, masuklah kamu kedalam Islam keseluruhan, dan janganlah kamu turut langkah-langkah syaitan. Sesungguhnya syaitan itu musuh yang nyata bagimu.

Dalam ayat ini dijelaskan bahwa: pertama, hai orang-orang yang beriman masuklah kamu sekalian ke dalam perdamaian. Janganlah kamu bermusuh-musuhan sesama kamu, karena orangorang yang beriman itu adalah bersaudara. Sebab itu wajiblah kamu hidup damai sesama kamu. Kedua, hai orang-orang yang beriman masuklah kamu ke dalam Islam seluruhnya, turutlah semua syari'atnya. Janganlah kamu ber-Islam dengan setengah-setengah, setengah syari'atnya kamu amalkan dan setengahnya kamu tinggalkan.

Berdasarkan definisi di atas maka dapat disimpulkan bahwa religuisitas adalah kedalaman penghayatan keagamaan seseorang dan keyakinannya terhadap adanya Tuhan yang diwujudkan dengan mematuhi perintah dan menjauhi larangan dengan keikhlasan hati dan dengan seluruh jiwa dan raga. Religiusitas juga diartikan sebagai keadaan yang terdapat dalam diri seseorang yang mendorong, berpikir, bersikap, berperilaku, dan bertindak sesuai dengan ajaran agamanya. 
Keberagaman atau religiusitas diwujudkan dalam berbagai sisi kehidupan. Aktivitas beragama bukan hanya terjadi ketika seseorang melakukan perilaku ritual (beribadah), tetapi ketika juga melakukan aktivitas lain yang didorong oleh kekuatan supranatural. Bukan hanya yang berkaitan dengan aktivitas yang tampak dan dapat dilihat mata, tapi juga aktivitas yang tak tampak dan terjadi dalam hati seseorang. Karena itu, keberagaman seseorang akan meliputi berbagai macam sisi atau dimensi. Seperti halnya dalam sistem nilai yang terdapat pada Swalayan Syariah akan ikut menentukan keputusan pembelian biasanya memerlukan pertimbangan-pertimbangan yang benarbenar mendukung.

\section{Lokasi}

Pemberi jasa, idealnya, memilih lokasi yang baik sebagai tempat usahanya, tempat yang disukai baik oleh produsen maupun konsumen. Letak perusahaan yang strategis dan mudah dijangkau oleh masyarakat diyakini akan lebih disukai konsumen dan akan lebih mudah memasarkan produk dan jasanya kepada pasar sasaran.

Perlu dicatat, bahwa di era majunya teknologi informasi saat ini banyak konsumen yang secara fisik tidak pernah mendatangi kantor/pabrik perusahaan penyedia layanan produk/jasa yang dibelinya. Di sisi lain banyak produsen/pribadi penyedia layanan produk/jasa tidak memiliki kedudukan yang tetap. Dalam hal ini lokasi yang dimaksud berada dalam dunia maya. Lokasi seperti ini tidak akan dibahas lebih lanjut dalam tulisan ini.

Lokasi perusahaan (secara fisik), perlu mendapatkan sorotan yang mendalam sebelum memutuskannya pada suatu tempat tertentu. Karena suatu keputusan yang diambil mengenai hal tersebut, memegang peranan dalam merealisir tujuan perusahaan yang didirikan. Pada permulaan pendirian suatu perusahaan persoalan mengenai lokasi perusahaan selalu muncul. Namun, tidaklah berarti apabila suatu perusahaan telah menjalankan aktivitasnya, maka persoalan letak perusahaan sudah bisa diabaikan. Sesungguhnya pemilihan lokasi perusahaan bukanlah semata-mata merupakan masalah bagi perusahaan yang akan didirikan. Banyak perusahaan industri terpaksa memindahkan lokasi karena beberapa sebab, antara lain habisnya bahan baku, tidak tersedianya tenaga kerja, dan sebagainya.

Penentuan lokasi suatu perusahaan merupakan salah satu kebijakan yang sangat penting. Perusahaan yang berada dalam lokasi yang strategis akan memudahkan pelanggan dalam berurusan dengan perusahaan. Disamping lokasi yang strategis, hal lain yang juga mendukung lokasi tersebut adalah layout gedung dan layout ruangan pelayanan. Penetapan layout yang baik dan benar akan menambah kenyamanan pelanggan dalam berhubungan dengan perusahaan. Pada akhirnya lokasi dan layout merupakan dua hal yang tidak terpisahkan dan harus merupakan suatu paduan yang serasi dan sepadan.

Secara umum ada beberapa tujuan yang hendak dicapai dalam penentuan lokasi dan layout ruangan/perusahaan, yaitu:

a) Agar perusahaan dapat menentukan lokasi yang tepat untuk lokasi kantor pusat, kantor cabang, lokasi pabrik, bengkel, gerai, dan lainnya.

b) Agar perusahaan dapat menentukan dan membeli atau menggunakan teknologi yang paling tepat dalam memberikan kecepatan dan keakuratan guna melayani konsumennya.

c) Agar perusahaan dapat menentukan layout yang sesuai dengan standar keamanan, keindahan, dan kenyamanan bagi konsumennya.

d) Agar perusahaan dapat menentukan kualitas tenaga kerja yang dibutuhkan sekarang dan di masa yang akan datang.

e) Agar perusahaan dapat menciptakan produk/jasa dengan biaya termurah sehingga diharapkan konsumen semakin menyukai produk/jasa yang mereka hasilkan.

Kemudian setelah lokasi diperoleh maka langkah selanjutnya adalah menentukan layout gedung dan ruang kantor. Hilangkan kesan kantor yang sumpek dan semrawut yang akan mengakibatkan pelanggan tidak betah berlama-lama berada di kantor. Usahakan layout ruangannya senyaman mungkin dengan susunan meja, tempat duduk atau keindahan lainnya seperti lukisan dan tersedianya musik sehingga pelanggan merasa nyaman.

Penentuan layout dapat dilakukan untuk dua macam yaitu layout gedung dan ruangan. Kedua layout ini saling mendukung kenyamanan pelanggan serta keamanan pelanggan dalam berurusan dengan perusahaan.

Lokasi perusahaan dapat dibedakan atas empat jenis lokasi yaitu:

a) Lokasi terikat pada Alam 
Lokasi perusahaan terikat pada alam ialah lokasi perusahaan yang tidak dipengaruhi oleh manusia, tetapi terikat pada alam. Misalnya lokasi perusahaan pertambangan harus di lokasi ditemukannya mineral, perusahaan pertanian harus didirikan di daerah dengan tanah dan iklim yang sesuai.

b) Lokasi berdasarkan sejarah

Lokasi perusahaan berdasarkan sejarah ialah bahwa perusahaan menjalankan aktivitasnya di suatu daerah hanya dapat dijelaskan berdasarkan sejarah. Contohnya adalah pabrik batik yang lokasinya di Yogyakarta. Mengapa justru di Yogyakarta dan kenapa tidak di Padangsidimpuan? Hal ini dapat dijelaskan berdasarkan sejarah. Pada mulanya industri batik yang ada di Yogyakarta, dimulai sebagai seni kerajinan yang dikerjakan oleh wanita di kraton. Seni kerajinan ini kemudian dicontoh oleh masyarakat umum, malahan sudah menjadi kebiasaan bahwa ketika tidak ada pekerjaan di sawah, para wanita mengerjakan pembatikan. Kemudian kegiatan pembatikan ini diorganisir sedemikian rupa di Yogyakarta. Karena itu di Yogyakarta didapati tenaga-tenaga pembatik yang berpengalaman.

c) Lokasi yang ditetapkan pemerintah

Lokasi ditetapkan pemerintah adalah lokasi tempat atau daerah yang ditetapkan pemerintah sebagai tempat khusus bagi perusahaan tertentu. Misalnya lokasi pemeliharaan babi dan lokasi pabrik senjata. Penetapan lokasi tersebut oleh pemerintah karena pertimbangan-pertimbangan tertentu, misalnya alasan kesehatan dan keamanan.

d)Lokasi atas dasar faktor ekonomi

Kimball Sr. dan Komball Jr., berpendapat bahwa faktor yang mempengaruhi pemilihan lokasi perusahaan khususnya industri (pabrik) adalah sebagai berikut: 1) Nearness to material, 2)Nearness to market, 3) Water power, 4)Supply of labour, 5)Favourable climate, 6) Capital available for investment.

Kedua faktor terdahulu merupakan faktor yang mendasar, karena tanpa bahan, perusahaan tidak mungkin bekerja. Tanpa pasar, tidak ada gunanya memproduksi barang sebab tidak laku. Sebenarnya ongkos pengangkutan mempengaruhi kedua faktor tersebut. Semakin kecil ongkos pengangkutan semakin tidak berpengaruh kedua faktor tersebut, sebaliknya semakin tinggi ongkos pengangkutan semakin berpengaruh kedua faktor tersebut. Faktor pasar dan faktor bahan mentah sering bertentangan dalam pemilihan lokasi perusahaan. Dimanakah perusahaan akan didirikan? Di dekat pasar atau dekat bahan mentah merupakan suatu pertanyaan yang tidak mudah untuk memecahkannya. Untuk menjawabnya perlu analisis dan kajian yang lebih komprehensif.

Ketersedian sumber daya air juga memegang peranan dalam penentuan lokasi perusahaan. Tenaga kerja juga berpengaruh dalam pemilihan lokasi perusahaan, baik mengenai jumlah, tingginya upah, dan kualitas tenaga kerja. Perusahaan cenderung mendirikan perusahaan di mana tenaga kerja banyak yang mau menerima upah yang reletif rendah.

Hal lain juga yang perlu diperhatikan adalah harga bahan mentah. Harga bahan mentah sangat penting, karena harga pokok barang jadi lebih dari setengahnya berasal dari harga bahan mentah. Setiap usaha untuk menurunkan harga bhan mentah akan menaikkan keuntungan, dan perusahaan akan memilih lokasi perusahaannya pada tempat di mana harga bahan termurah.

Penentuan lokasi perusahaan tidak dapat dilakukan secara sembarangan, tetapi harus mempertimbangkan berbagai faktor. Secara umum pertimbangan dalam menentukan lokasi perusahaan adalah sebagai berikut: 1) Jenis Usaha yang dijalankan, 2) Dekat dengan Pasar, 3) Dekat dengan Bahan Baku, 4) Dekat Tenaga Kerja, 6)Tersedia Sarana dan Prasarana (transportasi, listrik, dan air), 7) Dekat Kantor Pemerintahan, 7) Di Kawasan Industri, 7) Kemudahan untuk Ekspansi, 8) Adat istiadat / budaya/ sikap masyarakat, dan 9) Hukum yang berlaku.

Setelah penentuan lokasi selesai, maka langkah selanjutnya adalah menentukan layout gedung dan layout ruangan. Kedua hal ini sangat perlu diperhatikan guna memudahkan konsumen memperoleh keamanan dan kenyamanan dalam berhubungan dengan perusahaan. Seperti halnya dengan penentuan lokasi, penentuan layout juga harus memperhatikan dan mempertimbangkan beberapa hal.

Hal-hal yang perlu diperhatikan untuk layout gedung adalah sebagai berikut (terutama untuk perusahaan yang bergerak di bidang jasa):

a) Bentuk gedung yang memberikan kesan megah dan bonafid.

b) Lokasi parkir luas dan aman, hal ini memudahkan konsumen untuk melakukan transaksi dengan aman.

c) Keamanan di sekitar gedung juga harus dipertimbangkan dengan menyediakan pos keamanan yang dianggap perlu atau pemasangan kamera pengintai yang cukup. 
d) Tersedia fasilitas umum lainnya untuk konsumen misalnya, toilet, telepon umum, tempat ibadah dan sebagainya.

Sedangkan untuk layout ruangan yang harus diperhatikan adalah :

a) Suasana ruangan terkesan luas.

b) Tata letak meja dan kursi yang tersusun rapi dan dapat dengan mudah dipindah-pindahkan.

c) Hiasan dalam ruangan yang menarik, sebaiknya digunakan tanaman hias hidup.

d) Gambar-gambar dan hiasan dinding yang serasi dengan suasana ruangan dan pencahayaan yang baik.

e) Sarana hiburan seperti musik-musik lembut, sehingga ada rasa kenyamanan bagi konsumen dan berfungsi juga untuk mengusir kebosanan.

Sedangkan faktor-faktor yang menjadi pertimbangan dalam penyusunan layout peralatan adalah sebagai berikut: a) Produk yang dihasilkan, b) Kebutuhan terhadap ruangan, c) Urutan produksi, d) Jenis dan berat peralatan/mesin, e) Aliran bahan baku, f) Pemeliharaan, g) Flexibilitas (kemudahan berpindahpindah).

Jenis-jenis penyusunan layout peralatan dapat dibedakan menjadi:

a) Process layout (Functional layout)

Merupakan jenis layout dengan menempatkan mesin-mesin atau peralatan yang sama dalam satu kelompok atau satu ruangan. Contohnya semua mesin penghitung uang dikelompokkan dalam satu area.

b) Product layout (Flow Line layout)

Merupakan jenis layout dengan menempatkan mesin mesin atau peralatan yang berurutan sesuai dengan fungsinya masing-masing atau proses yang akan dikerjakan dalam satu kelompok atau ruangan. Dengan kata lain mesin atau peralatan disusun sesuai dengan urutan proses pengerjaan atau pelayanan.

\section{METODOLOGI PENELITIAN}

Jenis penelitian ini yang digunakan adalah penelitian kuantitatif. Asmadi Alsa (2004:13) menjelaskan bahwa penelitian kuantitatif adalah penelitian yang bekerja dengan angka, yang datanya berwujud bilangan ( skor atau nilai, peringkat, atau frekuensi), yang dianalisis dengan menggunakan statistik untuk menjawab petanyaan atau hipotesis penelitian yang bersifat spesifik, dan untuk melakukan prediksi bahwa suatu variabel yang lain atau dapat juga didefenisikan sebagai penelitian yang menggunakan asumsi-asumsi pendekatan positivistik.

Adapun Populasi yang dipakai dalam penelitian ini adalah keseluruhan mayarakat yang menjadi konsumen Rahmat Syariah Swalayan City Walk Padangsidimpuan yang jumlahnya tidak dapat ditentukan (tidak dapat diketahui) karena jumlahnya yang terus bertambah dan data domisilinya tidak diketahui.Untuk mengetahui jumlah sampel yang digunakan dalam penelitian ini, maka digunakan rumus sampel tidak diketahui sesuai dengan pendapat Husein Umar (2013:78) berikut:

Keterangan:

$$
\mathrm{n}=\mathrm{Z}^{2} \mathrm{P}(1-\mathrm{P}) / \mathrm{e}^{2}
$$

$\mathrm{n}=$ Ukuran sampel

$\mathrm{Z}=$ Mengacu pada tingkat kepercayaan. Dalam penelitian ini ditentukan sebesar $90 \%$ maka nilai Z adalah 1,65 .

$\mathrm{p}=$ Variasi populasi . Variasi populasi disini dinyatakan dalam bentuk proporsi, karena tidak ada data pendahuluan mengenai populasi, variasi populasi diasumsikan heterogen (dengan proporsi 50:50). Jadi, $0,5(1-\mathrm{p})=0,5 \times 0,5=0,25$

$\mathrm{e}=$ Kesalahan sampel yang ditolerir, dalam penelitian ini sebesar $10 \%$ dengan menggunakan rumus di atas, maka diperoleh perhitungan sebagai berikut:

$$
\begin{aligned}
& \mathrm{n}=\mathrm{Z}^{2} \mathrm{P}(1-\mathrm{P}) / \mathrm{e}^{2} \\
& \mathrm{n}=(1,65)^{2}(0,5)(1-0,5) /(0,1)^{2} \\
& \mathrm{n}=69
\end{aligned}
$$

Jadi sampel dalam penelitian ini adalah sebanyak 69 orang. 
Instrumen penelitian ini adalah menggunakan angket sebanyak 9 butir untuk variabel religiusitas $\left(\mathrm{X}_{1}\right)$ dan 10 butir untuk variabel lokasi $\left(\mathrm{X}_{2}\right)$, serta 13 butir untuk variabel keputusan pembelian $(\mathrm{Y})$. Pernyataan angket terdiri dari angket positif dan negatif seperti pada tabel berikut:

\section{Tabel 2: Daftar pernyataan angket}

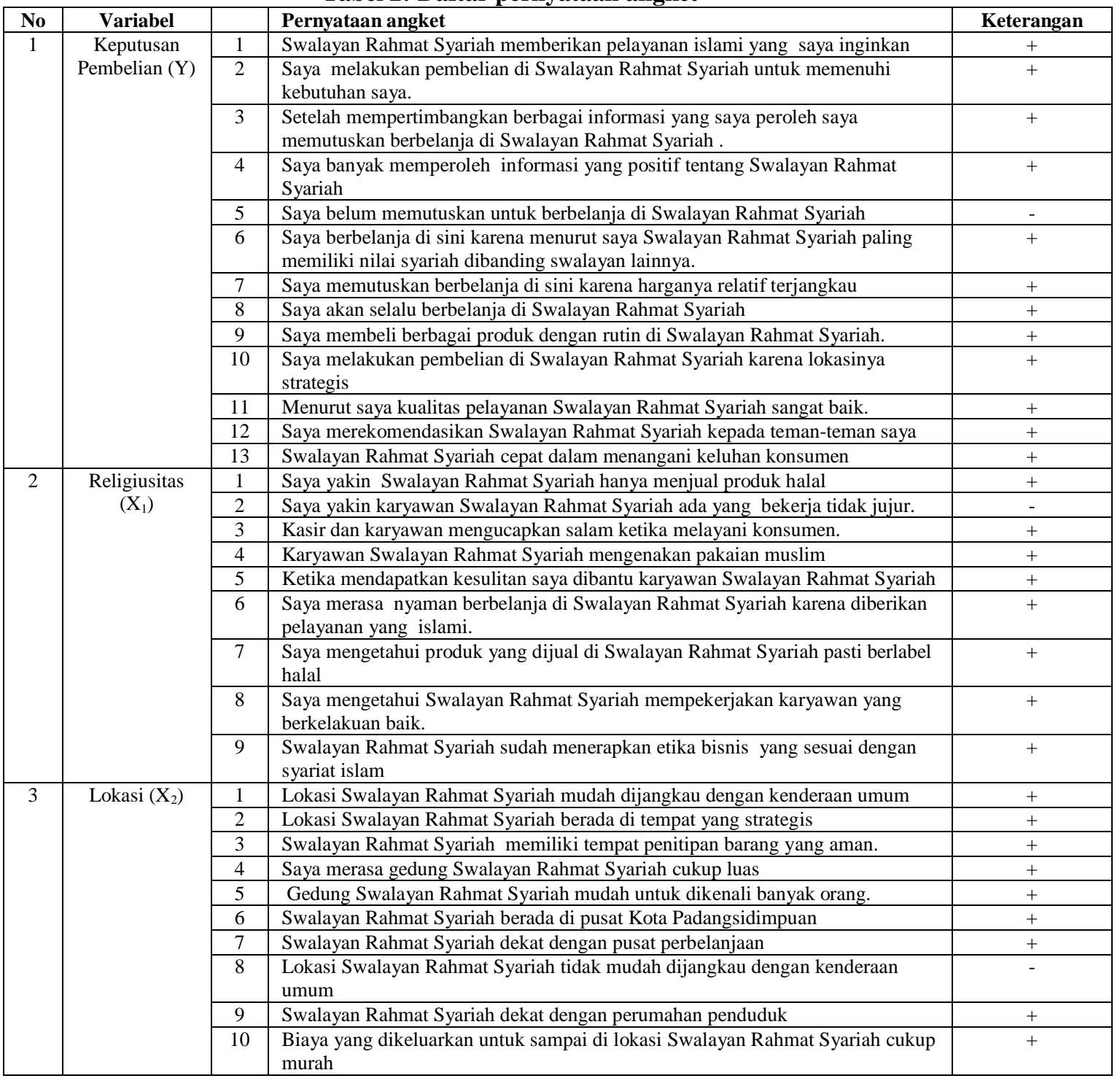

Bentuk angket yang digunakan adalah angket tertutup yaitu responden memilih jawaban yang telah disediakan sesuai dengan keadaan dirinya. Skala yang digunakan adalah skala likert, skala likert adalah skala yang berisi lima tingkat jawaban yang merupakan skala jenis ordinal. Di mana skala likert ini merupakan cara yang paling sering digunakan dalam menentukan skor. Angket ini menggunakan skala likert yaitu sebagai berikut :

Tabel 3: Skala Likert

\begin{tabular}{|c|c|c|}
\hline Kategori & Bobot $(+)$ & Bobot (-) \\
\hline Sangat Setuju & 5 & 2 \\
\hline Setuju & 4 & 3 \\
\hline Kurang Setuju & 3 & 4 \\
\hline Tidak Setuju & 2 & 5 \\
\hline Sangat Tidak Setuju & 1 & \\
\hline
\end{tabular}




\section{HASIL PENELITIAN}

\section{Uji Instrumen}

Berdasarkan uji validitas instrumen (angket) yang telah dilakukan ternyata sebanyak 9 butir untuk variabel religiusitas $\left(\mathrm{X}_{1}\right)$ dinyatakan valid dan 10 butir untuk variabel lokasi $\left(\mathrm{X}_{2}\right)$ juga dinyatakan valid. Sedangkan 1 dari 13 butir untuk variabel keputusan pembelian $(\mathrm{Y})$ dinyatakan tidak valid, yaitu butir angket nomor 5 sehingga tersisa 12 butir angket untuk variabel keputusan pembelian (Y) yang dinyatakan valid. Sehingga tahapan uji reliabilitas dapat dilanjutkan untuk semua butir angket yang valid tersebut.

Dari uji reliabilitas yang dilakukan diketahui bahwa angket sebanyak 9 butir untuk variabel religiusitas $\left(\mathrm{X}_{1}\right)$ dinyatakan reliabel dan 10 butir untuk variabel lokasi $\left(\mathrm{X}_{2}\right)$ dinyatakan reliabel, serta 12 butir angket untuk variabel keputusan pembelian (Y) juga dinyatakan reliabel.

\section{Uji Prasyarat}

Teknik uji normalitas yang digunakan adalah Kolmogorov-Smirnov pada taraf signifikansi 0,1 jika nilai $\mathrm{Sig}>0,1$ maka distribusi data bersifat normal dan jika $\operatorname{Sig}<0,1$ maka distribusi data tidak normal. Pengolahan data dilakukan dengan bantuan software SPSS, hasilnya seperti pada tabel berikut:

Tabel 4

Hasil Uji Kolmogorov Smirnov One-Sample Kolmogorov-Smirnov Test

\begin{tabular}{|c|c|c|c|c|c|}
\hline & & religiusitas & lokasi & $\begin{array}{l}\text { keputusan } \\
\text { pembelian }\end{array}$ & $\begin{array}{l}\text { Unstandardiz } \\
\text { ed Residual }\end{array}$ \\
\hline \multirow[t]{2}{*}{$\begin{array}{l}\text { N } \\
\text { Normal Parameters }{ }^{a, b}\end{array}$} & Mean & $\begin{array}{r}69 \\
30.55\end{array}$ & $\begin{array}{r}69 \\
34.52\end{array}$ & $\begin{array}{r}69 \\
46.41\end{array}$ & $\begin{array}{r}69 \\
.0000000\end{array}$ \\
\hline & $\begin{array}{l}\text { Std. } \\
\text { Deviation }\end{array}$ & 6.055 & 5.588 & 6.916 & 1.91334063 \\
\hline \multirow{4}{*}{$\begin{array}{l}\text { Most Extreme } \\
\text { Differences } \\
\text { Test Statistic } \\
\text { Asymp. Sig. (2-tailed) }\end{array}$} & Absolute & .078 & .085 & .076 & .054 \\
\hline & Positive & .078 & .085 & .073 & .052 \\
\hline & Negative & -.059 & -.057 & -.073 & -.054 \\
\hline & & $\begin{array}{l}.078 \\
.200^{c}\end{array}$ & $\begin{array}{l}.085 \\
.200^{\circ}\end{array}$ & $\begin{array}{l}.076 \\
.200^{c}\end{array}$ & $\begin{array}{r}.054 \\
.200^{c, d}\end{array}$ \\
\hline
\end{tabular}

a. Test distribution is Normal.

b. Calculated from data.

c. Lilliefors Significance Correction.

d. This is a lower bound of the true significance.

Dari hasil output SPSS uji normalitas di atas dapat dilihat bahwa data yang terkumpul memenuhi asumsi normalitas karena nilai signifikansi dari masing-masing variabel $>0,1$.

Selanjutnya dari uji linieritas yang dilakukan diperoleh tabel berikut:

Tabel 5

Hasil Uji Linieritas variabel $\mathrm{X}_{1}$ ANOVA Table

\begin{tabular}{|c|c|c|c|c|c|c|c|}
\hline & & & $\begin{array}{l}\text { Sum of } \\
\text { Squares }\end{array}$ & $\mathrm{df}$ & $\begin{array}{l}\text { Mean } \\
\text { Square }\end{array}$ & $\mathrm{F}$ & Sig. \\
\hline \multirow{5}{*}{$\begin{array}{l}\text { keput } \\
\text { usan } \\
\text { pemb } \\
\text { elian * } \\
\text { religiu } \\
\text { sitas }\end{array}$} & Between & (Combined) & 3073.331 & 23 & 133.623 & 33.535 & .000 \\
\hline & & Linearity & 2890.798 & 1 & 2890.798 & 725.492 & .000 \\
\hline & Groups & $\begin{array}{l}\text { Deviation from } \\
\text { Linearity }\end{array}$ & 182.533 & 22 & 8.297 & 2.082 & .019 \\
\hline & Within G & oups & 179.307 & 45 & 3.985 & & \\
\hline & Total & & $\begin{array}{r}3252.63 \\
8\end{array}$ & 68 & & & \\
\hline
\end{tabular}

Sumber: Output SPSS

Dari output di atas dapat diketahui bahwa signifikansi pada Linearity adalah sebesar 0,000. Karena signifikansi kurang dari 0,10 maka dapat disimpulkan bahwa antara variabel religiusitas dan keputusan pembelian terdapat hubungan yang linear. 
Tabel 6 : Hasil Uji Linieritas variabel $\mathbf{X}_{2}$ ANOVA Table

\begin{tabular}{|c|c|c|c|c|c|c|c|}
\hline & & & $\begin{array}{c}\text { Sum of } \\
\text { Squares }\end{array}$ & $\mathrm{df}$ & $\begin{array}{l}\text { Mean } \\
\text { Square } \\
\end{array}$ & $\mathrm{F}$ & Sig. \\
\hline \multirow{5}{*}{$\begin{array}{l}\text { keputusan } \\
\text { pembelian * } \\
\text { lokasi }\end{array}$} & \multirow{3}{*}{$\begin{array}{l}\text { Between } \\
\text { Groups }\end{array}$} & (Combined) & 2686.257 & 20 & 134.313 & 11.383 & .000 \\
\hline & & Linearity & 2593.023 & 1 & 2593.023 & 219.755 & .000 \\
\hline & & $\begin{array}{l}\text { Deviation } \\
\text { from Linearity }\end{array}$ & 93.233 & 19 & 4.907 & .416 & .980 \\
\hline & \multicolumn{2}{|c|}{ Within Groups } & 566.381 & 48 & 11.800 & & \\
\hline & \multicolumn{2}{|l|}{ Total } & 3252.638 & 68 & & & \\
\hline
\end{tabular}

Dari output di atas dapat diketahui bahwa signifikansi pada Linearity adalah sebesar 0,000. Karena signifikansi kurang dari 0,10 maka dapat disimpulkan bahwa antara variabel lokasi dan keputusan pembelian terdapat hubungan yang linear.

\section{Uji Asumsi Klasik}

Uji yang pertama adalah uji multikolinearitas. Dari output SPSS diperoleh tabel berikut:

Tabel 7 : Hasil Uji Multikolinearitas Coefficients $^{\mathrm{a}}$

\begin{tabular}{|c|c|c|c|}
\hline \multirow{2}{*}{\multicolumn{2}{|c|}{ Model }} & \multicolumn{2}{|c|}{ Collinearity Statistics } \\
\hline & & Tolerance & VIF \\
\hline & (Constant) & & \\
\hline & Religiusitas & .295 & 3.393 \\
\hline & Lokasi & .295 & 3.393 \\
\hline
\end{tabular}

a. Dependent Variable: keputusan pembelian

Berdasarkan tabel di atas dapat diketahui nilai VIF untuk variabel religiusitas adalah 3.393 $<10$,nilai VIF untuk variabel lokasi $3.393<10$. Jadi dapat disimpulkan nilai VIF dari kedua variabel diatas lebih kecil dari 10 (VIF <10). Sehingga berdasarkan nilai VIF tidak terjadi multikolinearitas..

Uji yang kedua adalah uji heterokedastisitas. Dari output SPSS diperoleh tabel berikut:

\section{Tabel 8 :Uji heterokedastisitas}

\section{Correlations}

\begin{tabular}{|c|c|c|c|c|c|}
\hline & & & religiusitas & lokasi & $\begin{array}{l}\text { Unstandardized } \\
\text { Residual }\end{array}$ \\
\hline \multirow[t]{3}{*}{$\begin{array}{l}\text { Spearman's } \\
\text { rho }\end{array}$} & Religiusitas & $\begin{array}{l}\text { Correlation } \\
\text { Coefficient } \\
\text { Sig. (2-tailed) } \\
\text { N }\end{array}$ & $\begin{array}{r}1.000 \\
69\end{array}$ & $\begin{array}{r}.872^{\star *} \\
.000 \\
69\end{array}$ & $\begin{array}{r}.036 \\
.772 \\
69\end{array}$ \\
\hline & Lokasi & $\begin{array}{l}\text { Correlation } \\
\text { Coefficient } \\
\text { Sig. (2-tailed) } \\
\text { N }\end{array}$ & $\begin{array}{r}.872^{\star *} \\
.000 \\
69 \\
\end{array}$ & $\begin{array}{r}1.000 \\
69\end{array}$ & $\begin{array}{r}.029 \\
.811 \\
69 \\
\end{array}$ \\
\hline & $\begin{array}{l}\text { Unstandardi } \\
\text { zed } \\
\text { Residual }\end{array}$ & $\begin{array}{l}\text { Correlation } \\
\text { Coefficient } \\
\text { Sig. (2-tailed) } \\
\text { N }\end{array}$ & $\begin{array}{r}.036 \\
.772 \\
69\end{array}$ & $\begin{array}{r}.029 \\
.811 \\
69\end{array}$ & 1.000 \\
\hline
\end{tabular}

Dari tabel di atas dapat dilihat bahwa nilai variabel independen memiliki nilai signifikan lebih dari 0,10 dimana religiusitas $\left(\mathrm{X}_{1}\right) 0,772>0,10$, lokasi $\left(\mathrm{X}_{2}\right) 0,811>0,10$, Maka dapat disimpulkan bahwa tidak terjadi masalah heterokedasitisitas pada model regresi. 


\section{Uji Koefisien Determinasi}

Dari output SPSS diperoleh tabel berikut:

Tabel 9: Hasil Uji Koefisien Determinasi Model Summary ${ }^{b}$

\begin{tabular}{|l|r|r|r|c|}
\hline Model & $\mathrm{R}$ & $\mathrm{R}$ Square & \multicolumn{1}{c|}{$\begin{array}{c}\text { Adjusted R } \\
\text { Square }\end{array}$} & $\begin{array}{c}\text { Std. Error of the } \\
\text { Estimate }\end{array}$ \\
\hline 1 & $.961^{\mathrm{a}}$ & .923 & .921 & 1.942 \\
\hline
\end{tabular}

a. Predictors: (Constant), lokasi, religiusitas

b. Dependent Variable: keputusan pembelian

Nilai koefisien determinasi adalah sebesar 0,923. Hal ini menunjukkan bahwa 92,3\% variabel religiusitas dan lokasi memengaruhi keputusan pembelian. Sedangkan sisanya sebesar 7,7\% dipengaruhi oleh faktor lain yang tidak diteliti dalam penelitian ini.

\section{Persamaan Regresi}

Dalam penelitian ini dilakukan perhitungan persamaan regresi linier berganda untuk mengetahui hubungan fungsional antara variabel religiusitas $\left(\mathrm{X}_{1}\right)$ dan variabel lokasi $\left(\mathrm{X}_{2}\right)$ dengan keputusan pembelian (Y) pada Rahmat Syariah Swalayan City Walk Padangsidimpuan.

Tabel 10: Persamaan regresi

Coefficients $^{\mathrm{a}}$

\begin{tabular}{|c|c|c|c|c|c|}
\hline \multirow[b]{2}{*}{ Model } & \multicolumn{2}{|c|}{ Unstandardized Coefficients } & \multirow{2}{*}{$\frac{\text { Standardized Coefficients }}{\text { Beta }}$} & \multirow[b]{2}{*}{$\mathrm{t}$} & \multirow[b]{2}{*}{ Sig. } \\
\hline & $\mathrm{B}$ & Std. Error & & & \\
\hline 1 (Constant) & 16.984 & 10.132 & & 1.676 & .098 \\
\hline religiusitas & 1.481 & .753 & .51 & 1.966 & .053 \\
\hline Lokasi & 1.291 & .776 & .43 & 1.669 & .101 \\
\hline
\end{tabular}

Berdasarkan tabel di atas dapat dibentuk persamaan regresinya sebagai berikut:

$$
\mathrm{Y}=\mathrm{a}+\mathrm{b}_{1} \mathrm{X}_{1}+\mathrm{b}_{2} \mathrm{X}_{2+} \mathrm{e}
$$

Keputusan Pembelian $=16,984+$ 1,481 Religiusitas+ 1,291 Lokasi +e

Dari persamaan regresi itu dapat diartikan bahwa:

a) Nilai konstanta sebesar 16,984 menunjukkan bahwa apabila religiusitas dan lokasi, dianggap konstan atau ditiadakan, maka keputusan pembelian konsumen di Rahmat Syariah Swalayan sebesar 16,984 satuan.

b) Nilai koefisien variaabel religiusitas sebesar 1,481, menunjukkan bahwa apabila religiusitas meningkat sebesar 1 satuan, maka akan meningkatkan keputusan pembelian sebesar 1,481 satuan, dengan anggapan variabel lain tetap. Koefisien bernilai positif artinya terjadi hubungan positif antara religiusitas dengan keputusan pembelian konsumen.

c) Nilai koefisien variabel lokasi sebesar 1,291 menunjukkan bahwa apabila kondisi lokasi semakin baik atau meningkat sebesar 1 satuan, maka akan meningkatkan keputusan pembelian konsumen sebesar 1,291satuan, dengan anggapan variabel lain tetap. Koefisien bernilai positif artinya terjadi hubungan positif antara lokasi dengan keputusan pembelian konsumen.

\section{Uji t}

Uji t digunakan untuk melihat seberapa jauh pengaruh variabel independen yaitu religiusitas dan lokasi secara individual dalam menjelaskan variasi variabel dependen yaitu keputusan pembelian. Adapun hasil dari uji signifikan parsial (uji t) adalah sebagai berikut:

Tabel 11: Uji t

Coefficients

\begin{tabular}{|c|c|c|c|c|c|c|}
\hline \multirow{2}{*}{\multicolumn{2}{|c|}{ Model }} & \multicolumn{2}{|c|}{ Unstandardized Coefficients } & \multirow{2}{*}{$\begin{array}{c}\begin{array}{c}\text { Standardized } \\
\text { Coefficients }\end{array} \\
\text { Beta }\end{array}$} & \multirow[b]{2}{*}{$\mathrm{T}$} & \multirow[b]{2}{*}{ Sig. } \\
\hline & & $\mathrm{B}$ & Std. Error & & & \\
\hline \multirow[t]{3}{*}{1} & (Constant) & 16.984 & 10.132 & & 1.676 & .098 \\
\hline & religiusitas & 1.481 & .753 & .511 & 1.966 & .053 \\
\hline & Lokasi & 1.291 & .776 & .432 & 1.669 & .101 \\
\hline
\end{tabular}

a. Dependent Variable: keputusan pembelian 
Penelitian ini menggunakan $\alpha=10 \%$. Dari tabel $\mathrm{t}$ diperoleh nilai $\mathrm{t}_{\alpha 2 \text { : df }}$ atau $\mathrm{t}_{0,05: 66}$ adalah 1,668.

Untuk variabel religiusitas diperoleh $t$ hitung $=1,966$. Oleh karena itu $t$ hitung $>t$ tabel atau $1,996>1,668$ sehingga $\mathrm{H}_{0}$ ditolak, artinya variabel religiusitas secara parsial memiliki pengaruh yang signifikan terhadap keputusan pembelian konsumen pada Rahmat Syariah Swalayan City Walk Padangsidimpuan.

Untuk variabel lokasi diperoleh $t$ hitung $=1,669$. Oleh karena itu $t$ hitung $>t$ tabel atau 1,669 > 1,668 sehingga $\mathrm{H}_{0}$ ditolak, artinya variabel lokasi secara parsial memiliki pengaruh yang signifikan terhadap keputusan pembelian konsumen pada Rahmat Syariah Swalayan City Walk Padangsidimpuan.

\section{Uji F}

Uji F bertujuan untuk mengetahui apakah variabel independen secara bersama-sama (simultan) yaitu religiusitas dan lokasi berpengaruh terhadap variabel dependen yaitu keputusan pembelian konsumen. Hasil uji simultan pada variabel ini adalah sebagai berikut:

Tabel 12: Uji F

ANOVA $^{\mathrm{a}}$

\begin{tabular}{|c|c|c|c|c|c|c|}
\hline \multicolumn{2}{|c|}{ Model } & $\begin{array}{l}\text { Sum of } \\
\text { Squares }\end{array}$ & Df & $\begin{array}{c}\text { Mean } \\
\text { Square }\end{array}$ & $\mathrm{F}$ & Sig. \\
\hline \multirow[t]{3}{*}{1} & Regression & 3003.698 & 2 & 1501.849 & 398.178 & $.000^{b}$ \\
\hline & Residual & 248.939 & 66 & 3.772 & & \\
\hline & Total & 3252.638 & 68 & & & \\
\hline
\end{tabular}

a. Dependent Variable: keputusan pembelian

b. Predictors: (Constant), lokasi, religiusitas

Berdasarkan tabel di atas dijelaskan bahwa religiusitas dan lokasi berpengaruh secara simultan terhadap keputusan pembelian konsumen padaRahmat Syariah Swalayan City Walk Padangsidimpuan karena nilai signifikansi $<0,1$ atau $0,000<0,1$.

\section{Pembahasan}

Dari hasil pengolahan data yang dilakukan menunjukkan secara parsial variabel religiusitas memiliki pengaruh yang signifikan terhadap keputusan pembelian pada Rahmat Syariah Swalayan City Walk Padangsidimpuan. Variabel lokasi juga memiliki pengaruh secara parsial yang signifikan terhadap keputusan pembelian konsumen pada Rahmat Syariah Swalayan City Walk Padangsidimpuan. Selanjutnya secara simultan religiusitas dan lokasi berpengaruh secara signifikan terhadap keputusan pembelian konsumen padaRahmat Syariah Swalayan City Walk Padangsidimpuan. Hal ini mengisyaratkan agar Rahmat Syariah Swalayan City Walk Padangsidimpuan tetap mempertahankan nilai-nilai religiusitas dalam melayani konsumennya karena ternyata variabel ini masih menjadi salah satu faktor yang mempengaruhi keputusan konsumen untuk berbelanja di Rahmat Syariah Swalayan City Walk Padangsidimpuan. Dengan demikian diharapkan jumlah pelanggannya dapat meningkat di masa yang akan datang. Hal ini menjadi penting karena saat ini swalayan sejenis yang bernuansa religius di Kota Padangsidimpuan bukan hanya didominasi oleh grup Rahmat Syariah Swalayan. Di Kota Padangsidimpuan juga telah hadir 212 Mart. Faktor kestrategisan lokasi juga perlu dipertimbangkan oleh pihak manajemen Rahmat Syariah Swalayan karena memiliki pengaruh yang signifikan terhadap keputusan konsumen untuk berbelanja. Secara simultan variabel lokasi dengan variabel religiusitas memberikan kontribusi sebesar 92,3\% terhadap keputusan pembelian konsumen pada Rahmat Syariah Swalayan City Walk Padangsidimpuan. Artinya kontribusi kedua faktor ini sangat besar dan harus menjadi perhatian utama pihak manajemen Rahmat Syariah Swalayan City Walk Padangsidimpuan. Namun beberapa faktor lain juga tidak boleh dikesampingkan yaitu: harga, citra, kelengkapan fasilitas, kecepatan pelayanan, dan lainnya

Kemudian dari uji regresi linier berganda diperoleh persamaan sebagai berikut:

Keputusan Pembelian $=16,984+$ 1,481 Religiusitas + 1,291 Lokasi +e

Dari persamaan di atas terlihat bahwa koefisien variabel Religiusitas dan Lokasi bernilai positif (+). Hal ini menunjukkan adanya hubungan yang positif atau searah antara variabel Religiusitas dan Lokasi dengan Keputusan Pembelian. Artinya dengan meningkatkan nilai Religiusitas dan Lokasi maka akan meningkatkan keputusan pembelian konsumen pada Rahmat Syariah Swalayan City Walk Padangsidimpuan juga. 
Hasil penelitian ini secara umum sejalan dengan beberapa penelitian terdahulu, antara lain dengan penelitian yang dilakukan oleh Sukesti dan Budiman (2014) dari Fakultas Ekonomi Universitas Muhammadiyah Semarang. Mereka menemukan bahwa ada pengaruh label halal dan religiusitas personal terhadap keputusan pembelian produk makanan di Indonesia. Penelitian ini juga sejalan dengan penelitian yang dilakukan oleh Sadzalia (2015) dari Universitas Islam Negeri Maulana Malik Ibrahim Malang. Ia menemukan bahwa secara simultan variabel label halal dan variabel religiusitas berpengaruh signifikan terhadap variabel keputusan pembelian produk kosmetik di kota Malang.

\section{KESIMPULAN}

Dari hasil penelitian yang telah dilakukan disimpulkan bahwa secara parsial dan simultan variabel religiusitas dan variabel lokasi memiliki pengaruh yang signifikan terhadap keputusan pembelian konsumen pada Rahmat Syariah Swalayan City Walk Padangsidimpuan. Variabel religiusitas dan variabel lokasi memberikan kontribusi sebesar 92,3\% terhadap keputusan pembelian konsumen pada Rahmat Syariah Swalayan City Walk Padangsidimpuan, sedangkan sisanya 7,7\% dipengaruhi oleh variabel lain yang tidak diteliti dalam penelitian ini.

\section{DAFTAR PUSTAKA}

Al-Qur'an dan Terjemahannya

A. Abdul Hakim \& JaihMubarok (2004), MetodologiStudi Islam. Bandung: Remaja Rosdakarya Offset.

Abuddin Nata (2010), Akhlak Tasawuf, Jakarta: Rajawali Pers.

Alma, Buchari (2016), Manajemen Pemasaran dan Manajemen Jasa, Bandung: CV

Alfabeta.

Asmadi Alsa (2004), Pendekatan Kuantitatif \& Kualitatif Serta Kombinasinya dalam Penelitian Psikologi, Yogyakarta: Pustaka Pelajar.

Asep ST Sujana (2012), Manajemen Minimarket, Depok: Penerbit RAS.

Etta Mamang Sangadji \& Sopiah (2013), Perilaku Konsumen: Pendekatan Praktis Disertai Himpunan Jurnal Penelitian, Yogyakarta :CV. Andi Offset.

Fandy Tjiptono (2015), Strategi Pemasaran, Yogyakarta:Andi.

Faiz Mujawidin (2014), "Bank Selection Criteria: Tingkat Religuisitas dan Pengaruhnya", Surakarta: Skripsi Sekolah Tinggi Ilmu Ekonomi Swasta Mandiri Surakarta.

Nugroho J. Setiadi (2010), Perilaku Konsumen:Perspektif Kontemporer Pada Motif, Tujuan dan

Keinginan Konsumen, Jakarta: Kencana Prenada Media Group.

Nurzaman, Kadar (2013), Manajemen Perusahaan, Bandung: Pustaka Setia.

Shihab, M. Quraish (2002), Tafsir Al-Misbah, Jakarta: Lentera Hati.

Susatyo Herlambang (2014), Basic Marketing: Cara Mudah Memahami Ilmu Pemasaran, Yogyakarta: Gosyen Publishing.

Umar, Husein (2013), Metode Penelitian untuk Skripsi dan Tesis, Edisi Kedua, Jakarta:

Rajawali Pers.

Yazid, (2008), Pemasaran Jasa: Konsep dan Implementasi, Yogyakarta: Ekonisia. 